\title{
Draughtsmen in Zambia
}

Senior Draughtsman must have had considerable experience in preparation of multicolour maps and of photogrammetrical methods of compilation. Will take charge of Geological Survey Office Services.

Salary $£ \mathrm{r}, 596-£ \mathrm{r}, 876$ approx. plus inducement allowance $£ 714$ p.a. Contract 2-3 years. $\mathrm{M}_{3} \mathrm{C} / 700316 / \mathrm{GV}$.

Draughtsmen also in the Geological Survey Dept. Sound draughtsmen with some knowledge of topographical, geological and topographical map compilation from air photographs.

Salary $£_{1}, 057-£ 1,876$ approx. plus inducement allowance $£_{564-£_{7} 14}$ p.a. Contract 3 years. $M_{3} C / 69$ IIOI $/ G V$.

Draughtsman with at least five years draughting experience, including three years in cartographic duties, and a knowledge of photogrammetry and lithography.

Salary $£ 1,057-£ 1,876$ approx. plus inducement allowance $£ 564-£ 714$. Contract 3 years. $M_{3} C / 7004 I 2 I / G V$.

Apply to CROWN AGENTS, 'M' Division, 4 Millbank, London, S.W.I' for application form and further particulars stating name, age, brief details of qualifications and experience and quoting relevant reference number.

\section{UNIVERSITY COLLEGE, DUBLIN}

\section{Assistant or Assistant Lecturer in the Department of Geology}

Applications are invited for the post of Mineralogist-in the Department. Particular emphasis is laid on research accomplishment, and the post will provide scope for such work. Applicants should be of doctoral standing, and preferably have published research.

The annual salary attached to the post is:

Assistant: $£ 1190 \times 66-£ 1322$.

Assistant Lecturer: $£ 1388 \times 88-£ 1997$.

Salary and entry point on the scale in accordance with qualifications and experience.

Non-contributory pension and family allowances are additional to salary.

Applications, in triplicate stating qualifications and experience and including curriculum vitae and testimonials, together with the names of two referees, should reach the undersigned, from whom further particulars may be obtained.

The Professor of Geology,

University College, Belfield,

Stillorgan Road, Dublin 4. 


\section{CANADA}

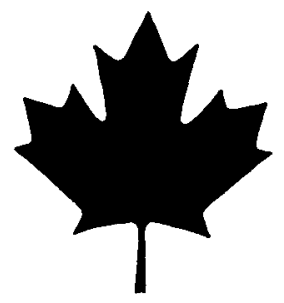

\section{GOVERNMENT OF SASKATCHEWAN}

Precambrian Geologists (M.Sc. or PhD) to lead five-man summer field parties in geological mapping in the Precambrian Shield area of Saskatchewan and after laboratory studies to prepare reports for publication.

Sedimentary Geologist (Honours Degree or Degree in Geological Engineering) to pick formation boundaries from mechanical logs, examine cores and samples and prepare maps, cross-sections and reports for publication.

Geophysicist (Graduate in Geophysics or equivalent) for checking incoming data, inspecting field operations, organising studies for departmental use and publication and reviewing regulations. Qualifications must include professional experience in exploration work with emphasis on interpretation.

Satisfactory commencing salaries will be paid depending upon experience and training.

Please contact Mr. W. C. A. Knights, Immigration Department, Government of Saskatchewan, 28 Chester Street, S.W.1. (01-235-1871). 
Articlessubmitted for publication in the Geological Magazine should be addressed to the editors at the Sedgwick Museum, Downing Street, Cambridge $\mathrm{CB}_{2}{ }_{3} \mathrm{EQ}$, England, and sent in duplicate. Publications for notice and review should be marked for the review editor at the same address.

Contributions, including reference lists, should be typewritten, double-spaced, and should be carefully revised. Where typing errors are corrected or minor alterations made, they should be done neatly in the typescript, leaving the margins clear. Marginal marks should be used only when correcting proofs. Illustrations should be drawn to allow reduction to a maximum size of $165 \mathrm{~mm} \times 1$ I omm; originals must not exceed $495 \mathrm{~mm} \times 33 \mathrm{omm}$ and must be sent in a flat package. Lettering must allow for legibility after reduction (i.e. equivalent to $\mathrm{Imm}$ as a minimum on reduction). Duplicates of illustrations may be prints or, preferably, reductions. Metric units of the SI system are preferred. Illustrations in the text will be referred to as figures (Fig. I, $\mathrm{I} a$, etc.), and halftone plates will be referred to (also in arabic) as Plates $\mathrm{I}, \mathrm{I} a$, etc. Folding plates will not be accepted. Captions must be typed on separate sheets.

The typescript must be accompanied by a short summary. Contributors should follow the rules in the Geological Society of London's Notes to Authors (Proc. geol. Soc. Lond., No. ${ }^{62} 7$, Oct. 1965), with the following exceptions. The total length of a paper should not in general exceed 20 pages of the Geological Magazine; preference and priority are given to short papers. Primary headings should be in capitals, at margin, with arabic numeral; secondary headings should be in lower case (not underlined), with lower case letter in parentheses; tertiary headings should be in lower case italics (underlined), at margin, with lower case roman numeral in parentheses, (i), (ii), etc.

No cross-references by page should be given to other parts of the text, but 'above' and 'below' used (with the section specified, e.g. 'Section $2 a$ (i)'). References should be abbreviated in the form of the World List of Scientific Periodicals (4th edit., I $963-65$ ) as far as possible. e.g. Lapworth, C. 1878 . The Moffat Series. Q. $7 l$ geol. Soc., Lond., 34, 240-343. Books should be cited briefly as: Burns, R. G. 1970. Mineralogical applications of crystal field theory. 224 p., C.U.P., London. Unpublished work, e.g. from theses, should normally be referred to in the text in parentheses and not included in the reference list unless already in the press.

Twenty-five offprints of each paper will be provided free of charge. Additional offprints may be purchased according to an agreed scale of charges. 


\section{Geological Magazine}

\section{Volume 107, Number 1, January 1970}

CAMPBELL, I.H., McGALL, G.J.H. \& TYRWHITT, D.S.

The Jimberlana Norite, Western Australia-a smaller analogue of the Great Dyke of Rhodesia.

JONES, J.G. \& NELSON, P.H.H.

The flow of basalt lava from air into water-its structural expression and stratigraphic significance.

HUGHES, C.J.

The significance of biotite selvedges in migmatites.

A note on some garnetifierous biotite schists from Gangpur, Eastern India, and their polyphase metamorphism.

KUMAR, SURENDAR

Oolites and deformation.

WOLFE, M.J.

Dolomitization and dedolomitization in the Senonian chalk of Northern Ireland.

WARREN, P.T., HARRISON, R.K., WILSON, H.E., SMITH, E.G. \& NUTT, M.J.C.

Tectonic ripples and associated minor structures in the Silurian rocks of Denbighshire, North Wales.

DENNESS, BRUCE

A method of contouring polar diagrams using curvilinear counting cells.

HUTT, JANA \& RICKARDS, R.B.

The evolution of the earliest Llandovery Monograptids.

COCKS, L.R.M., TOGHILL, P. \& ZIEGLER, A.M.

Stage names within the Llandovery Series.

CORRESPONDENCE

Ages of Tertiary rocks at Uloa and Umkwelane, Zululand, and their geomorphological significance.

Shelton P. Applegate. 